Article

\title{
Mitigating Pro-Poor Housing Failures: Access Theory and the Politics of Urban Governance
}

\author{
Katja Mielke ${ }^{1, \dagger}$ and Helena Cermeño ${ }^{2, *, \dagger}$ \\ ${ }^{1}$ Bonn International Center for Conversion (BICC), Germany; E-Mail: katja.mielke@bicc.de \\ ${ }^{2}$ Department of Urban Sociology, University of Kassel, Germany; E-Mail: hcermeno@asl.uni-kassel.de \\ * Corresponding author \\ † These authors contributed equally to this work
}

Submitted: 30 January 2021 | Accepted: 23 March 2021 | Published: 25 June 2021

\begin{abstract}
Looking at evolving urban governance and planning practices in the city of Lahore, Pakistan, the article aims to understandfrom an Evolutionary Governance Theory perspective-to what extent these practices steer paths and modes of service provision and housing for low-income residents. With a focus on the endurance and transformations of urban governance practices and institutions, we first explore the influence of the changing development discourse and the impact it has had on the (re)configuration of urban governance and housing policies in Lahore. Second, drawing on extensive fieldwork and empirical data collected between 2012 and 2016, we highlight three vignettes depicting the development of different housing options for low-income residents in Lahore, i.e., a government-steered subsidised housing scheme, a privately developed 'pro-poor' settlement in the peri-urban fringe of the city, and residential colonies already-or in the process of being-regularised. By analysing the relationship between governance frameworks, the establishment of the three types of settlements and how residents manage to access housing and services there, we demonstrate how purposive deregulation in governance and policy generates a disconnect between urban normative frameworks (i.e., urban planning tools and pro-poor housing policies) and residents' needs and everyday practices. We argue that this highly political process is not exclusively path-dependent but has also allowed the creation of liminal spaces based on agency and collective action strategies of low-income residents.
\end{abstract}

\section{Keywords}

access theory; evolutionary governance theory; Lahore; low-income housing; Pakistan; planning; power; pro-poor housing; steering; urban politics

\section{Issue}

This article is part of the issue "Steering in Governance: Evolutionary Perspectives" edited by Kristof Van Assche (University of Alberta, Canada / University of Bonn, Germany) and Raoul Beunen (Open University, The Netherlands).

(C) 2021 by the authors; licensee Cogitatio (Lisbon, Portugal). This article is licensed under a Creative Commons Attribution 4.0 International License (CC BY).

\section{Introduction}

When Pakistan was created in 1947, the city of Lahore typified differentiated urban qualities and socioeconomic disparities in the planned civil station versus indigenous settlements (Qadeer, 1983). The effects of colonial development such as the morphological differences between newer districts and older areas of native habitation, the socio-spatial segregation, the exclusionary patterns of housing and service provision, as well as the British-Indian urban governance regulations and institutions, constituted a specific legacy for post-colonial Lahore (Alvi, 1997; Malik, 2011). When about five million Muslims sought refuge in West-Punjab due to partition politics that resulted in the greatest displacement of the 20th century, Punjab's capital Lahore bore the brunt of the mass influx, and ever since, the question of housing provision-especially for 
low-income residents-has been pertinent and highly politicised. The current government, for instance, rolled out the "Naya (New) Pakistan Housing" programme in 2018, promising 'affordable housing' for low-income populations. Against a current estimated national housing backlog of 11 to 12 million housing units-four million only in urban areas-the "Housing for All" (sub)programme claims to provide five million housing units within a "100 Days Agenda" (Government of Pakistan, 2018). Similar previous steering attempts to mitigate the increasing housing backlog have largely failed. In Lahore, Pakistan's second-largest city with an estimated population of approximately 11.1 million inhabitants in 2017 (Pakistan Bureau of Statistics, 2017), the fast-paced development of housing schemes in the peri-urban fringe has hardly contributed-if at all over the years - to addressing the housing needs of low-income and vulnerable populations (Anjum \& Hameed, 2007).

In this article, we analyse the transforming modes, practices, and strategies of planning and urban governance in Lahore for pro-poor housing from an Evolutionary Governance Theory (EGT) perspective (Van Assche et al., 2014) that understands governance and its constitutive elements as relational and in constant flux. We focus on how actors and institutions involved in spatial planning over time have dealt with, perpetuated and/or undermined path dependencies, and become entangled through goal- and interdependencies. Although these dependencies can constrain the evolution of planning perspectives over time and lead to the reproduction of already existing modes of planning and governance-and their underlying mechanisms of power and control-we intend to scrutinise to what extent and under which conditions they become productive in the sense that they create opportunities for alternative governance paths. We argue that the combination of EGT perspectives with access theory is conceptually fruitful to understand: a) the extent to which these dependencies ultimately steer modes of access to housing and service provision for low-income residents; and $b$ ) if and how path creation might shape modes of beneficiaries' agency and collective action strategies from below.

For evidence, we turn to three steering processes in pro-poor urban housing governance: A governmentinitiated subsidised housing scheme, a privately developed pro-poor settlement in the peri-urban fringe of the city, and residential colonies in the process of regularisation. For each of these case study vignettes, we analyse how different actor/institution configurations governed the respective pro-poor housing scheme and how steering affected low-income families' ability to obtain houses and services. The individual governance paths are highlighted for each case study by outlining first the planning aspiration and steps taken for implementation, followed by an access mapping (Ribot $\&$ Peluso, 2003), i.e., the analysis of mechanisms by which the supposed beneficia- ries are enabled or constrained in sustaining low-income housing and services. In a third empirical step, we draw attention to existing path dependencies, interdependencies, and mechanisms of non-linear path creation characteristic for each case study context. The analysis is based on extensive qualitative social science research conducted between 2012 and 2016. The insights from a synthesis of all three case studies enable us to derive conclusions regarding the wider effects of steering, i.e., whether and how sustained access to low-income housing is ensured and could thus be evaluated as a meaningful contribution to mitigating the housing crisis for Lahore's poor. In the conclusion, we reflect on the added value of combining EGT and access theory for the theory and practice/s of steering and for understanding the politics of low-income housing provision in and beyond Pakistan.

\section{Bringing Access Theory into EGT to Account for Power Relations in Governance Analysis}

Steering comprises both planning and efforts at implementation that manifest in governance effects. We understand governance (paths) as histories of steering attempts. As EGT scholars have pointed out previously (Beunen et al., 2017), social engineering effects are most likely to take shape in autocratic or centralised societies; yet overall, they are overestimated in particular, "[i]f on the other hand, localism, individualism and legalism dominate the governance path, it is unlikely that a plan does much outside the planner's office" (Van Assche et al., 2014, p. 90). The quote hints at the empirical reality that where no top-down management enforces governance visions, they fail in practice-from the perspective of those governing. However, from an analytical perspective, non-linear path creation can be considered as productive because it has the potential to open spaces for dissent, innovation and adaptation. Since EGT conceptual frameworks have largely disregarded power relations between governance actors and institutions so far (Beunen et al., 2015, p. 332), it has remained inconclusive why steering attempts fail to meet their intentions. We argue that access theory has an important contribution to make in clarifying this relationship.

Access theory locates power in social relations and ongoing struggles within them (Peluso \& Ribot, 2020, p. 300). These relationships between actors and institutions or sets of relationships (bundles of powers) constitute access mechanisms that determine who can benefit from resources-in our case low-income housing and services. Access itself is defined as the ability to benefit from a certain resource (Peluso \& Ribot, 2020; Ribot \& Peluso, 2003) which does not presume ownership or require property rights as a precondition for benefit. The focus on the ability (to benefit) extends beyond rights. Mechanisms of access are subsequently differentiated between rights-based mechanisms (based on the observation or ignorance of law, thus including, 
e.g., 'illegal' access through force) vs. structural and relational mechanisms that shape how benefits are gained, controlled, and maintained-possibly facilitated utilising technology (physical barriers), capital/finances, knowledge, authority, identity, and social relationships. Access analysis comprises the identification of access mechanisms and underlying power relations in actor/institution configurations. For our case, the conceptual merger of both strands of scholarship allows us to investigate to what extent evolving planning perspectives and governance frameworks ultimately shape, constrain, or limit residents' ability to access housing and related services.

By combining access theory with selective EGT concepts (e.g., non-linear paths and dependencies), we extend EGT conceptually (Van Assche et al., 2014) and illustrate how an analysis of governance paths that accounts for the analysis of power relations that underly access mechanisms will reveal limits of steering (Van Assche \& Verschraegen, 2008) and social engineering. This is based on the premise that power relations shape governance arrangements, outcomes, and the evolution of governance itself. EGT research illustrates that actor/institution configurations and their respective planning visions, once established, tend to reproduce themselves (Beunen et al., 2017, p. 102). Planning perspectives - specific narratives, specific ways of reading, and managing socio-spatial realities-tend to reinforce their own constructions of reality, existing power relations, and actor/institution configurations. In doing so, they create path dependencies i.e., legacies of the past in different forms that affect governance evolution over time, contribute to the rigidity of planning (Beunen et al., 2015; Van Assche et al., 2014) and constrain its adaptation to an otherwise changing environment. Strong path dependencies can not only lead to higher levels of resilience to change but also tend to foster oversimplified planning perspectives. As pathdependent planning, governance frameworks and development discourses can no longer cope with the transformation of society and the increasing complexity of urban realities, they might gradually result in a larger disconnect between the perceived problems and suggested strategies from the planning perspective and the actual societal needs (Beunen et al., 2017).

The underlying aims and future visions of many planning and development interventions are likewise embedded with goal dependencies. These refer to the shared visions for the future within a given actor/institution configuration that contribute to how governance practices and mechanisms of control, such as plans, policies, and laws are delineated (Beunen et al., 2015). The more linear and homogeneous the vision of the future is-such as in modernisation paradigm in development theorywithin a given actor/institution configuration, the less flexible and adaptable the governance framework will be, and the less able it is to shape non-linear, alternative creative paths to tackle context-specific and emerging sociospatial challenges.

\section{The Evolution of Lahore's Urban Governance Framework}

The trajectory of pro-poor housing governance and related urban steering in Pakistan and specifically in Lahore has evolved through close entanglements between development planning at national and subnational levels and international development discourses ('fashions'), funding institutions, and consultancies. The multifarious mutual relations between international discourses and national steering intentions in the policy field of housing-besides representing de facto goal dependence-have produced specific actor/institution configurations in Lahore's pro-poor housing sector. From its infancy years, Pakistan's administrations were linked to modernisation theory-inspired development planning and related aid disbursements, e.g., through the "Truman's Four Point" programme and the first Five Year Development Plan (1955-60) prepared by Harvard University academics. In the tradition of Walter Rostow's 'stages of economic growth,' Ayub Khan's government (1958-69) emphasised high industrialist-capitalist development under the tutelage of a military bureaucracy. While the World Bank and the government itself viewed the process favourably and the latter was preparing for grand celebrations of the 'decade of development' in 1968/69, many parts of the country were in the grip of popular protests by those who did not benefit from economic growth. Already in the 1970s-80s, about 75 percent of Lahore's population could not afford land at market price (Alvi, 1997; Qadeer, 1983). Large parts of the population could not afford to own housing and had to resort to renting options, adding progressively to existing housing to host new family members or encroaching on state land. The authorities either demolished or ignored irregular housing, locally referred to as katchi abadis, for many years. The large proportion of the urban and rural population that depended on irregular housing formed a veritable political constituency, increasingly able to formulate political demands. These resonated initially with Zulfiqar Ali Bhutto's leftist party in the 1970s, which won elections with the prospect of granting the poorest housing and ownership rights, captured in the slogan "Roti, Kapra aur Makan" ("Bread, Cloth and Shelter"). Even though the success of the Bhutto government (1971-77) in addressing the housing question was limited, the politicisation of the issue mobilised the urban poor around the cause of urban housing and the subject of katchi abadis so that all political parties included housing as a subject in their election manifesto by 1977 (Alvi, 1997).

In this context, the Lahore Urban Development and Traffic Study 1980 (LUDTS, 1981-2000) was compiled as a "structure plan" (Javed \& Riaz, 2020, p. 155) with an inherent focus on providing access to services and supporting informal housing for low-income groups. In line with the development paradigm at that time, the LUDTS focused on the neighbourhood (mohalla) level, 
mirroring the international trend to prioritise structural plans and action planning approaches (Jenkins et al., 2007). As it attributed a decisive role to local level planning and implementation-in this case, the successor authority of the colonial Lahore Improvement Trust that was revamped as Lahore Development Authority (LDA) in 1975-it also incorporated the World Bank's focus on homeownership and security of tenure in land and housing for the urban poor. In addition, other 'travelling ideas,' rooted in the basic needs and redistribution of growth development theories of the 1970s (Jenkins et al., 2007; Qadeer, 1983, p. 255), manifested in aided self-help housing programmes and progressive development strategies (such as 'sites and services').

The military government of Zia-ul-Haq (1978-88) addressed the issue of access to low-income housing in the 1981 National Housing Policy (NHP) and the establishment of provincial Katchi Abadis Directorates financed by loans of Structural Adjustment Programmes (Gera, 2007). The "One Million Houses" programme that promised to construct 1.5 million housing units by 1993 , projecting to have the first 300,000 units ready by 1988 , i.e., within two years (Alvi, 1997, pp. 74-75), remained far behind expectations with just about 35,000 units constructed. Subsequent public sector initiatives for pro-poor housing schemes followed this precedent (Rana, 2013). Until the late 1990s, master plans and housing and development programmes rolled out in Pakistan and Lahore in particular failed to address the housing problem for low-income populations. Regularly, ambitious public sector pro-poor housing programmes, aligned with international aid and development funding lines, were announced as flagships of newly established governments, then delayed and ultimately abandoned with the coming of a new administration. An insufficient allocation of funds for low-income housing and services among development authorities and local governments hindered implementation. Moreover, early subsidised sites and services programmes in Lahore in the 1950s (e.g., in Samanabad and Gulberg) simply lacked a propoor focus or experienced gentrification (Alvi, 1997, p. 57; Qadeer, 1983). Consequently, planning scholars and practitioners in Pakistan eagerly picked up the turn to an affordability approach to low-income housing, which was also promoted by the World Bank (Ahsan, 2019; Fariha et al., 2018). This paradigm shift ascribed the private sector the central role for housing development. Accordingly, the NHP-2001 merely established guidelines for developing provincial housing policies and the coordination between federal, provincial and urban local bodies, but de facto had little impact on low-income housing planning. Recently, the global trend of corporatisation was accounted for in Lahore when public sector companies owned by the provincial government or its public sector departments entered the market to provide public utilities and consultancy services.

Although the effort to comply with the Millennium Development Goals on urban poverty reduction and slum improvement can be traced in the NHP-2001 and the later Task Force Report on Urban Development 2011, on the provincial level, it has mainly translated into regularisation programmes for informal settlements (katchi abadis). After their initiation under Bhutto's government, subsequent alternating civilian and military governments continued with the regularisation of katchi abadis as their main and most resilient government strategy for low-income housing. With an inherent property rights approach (de Soto, 2001), however, these policies raise questions about their effectiveness in improving access to housing and adequate services for low-income and vulnerable populations.

The evolution of the urban governance framework and the urban planning regulatory instruments and institutions has followed a non-linear transformation process, in which interdependencies, gaps, overlaps, and failures characterise actor/institution configurations. Even the devolution of powers to the provincial level from 2010 onwards has not eased fragmented planning. Local urban governance has evolved, closely interlinked with Local Government Acts of the day, which time and again reshaped administrative boundaries and institutional-jurisdictional mandates with each new incoming government. Actor/institution configurations operating under the Ministry of Defence blurred the urban governance framework further (Cermeño, 2021). As a result, a myriad of governing bodies responsible for planning and implementation coexist. The largest one, the LDA-an autonomous body under the provincial Secretary of Housing Urban Development \& Public Health Engineering Department (HUD\&PHE) - covered the Lahore Metropolitan Area, approximately 1,760 square kilometres in the 1980s, and gradually expanded to around 2,306 square kilometres in 1988, before it expanded further to include four districts: Lahore, Sheikhupura, Nankana Sahib, and Kasur in 2013 (Javed \& Riaz, 2020). In contrast, the Punjab Housing and Town Planning Agency, also under the HUD\&PHE, is responsible for the overall spatial planning in Punjab Province, the implementation of the NHP, and the development of social housing projects on public land, such as the current government's "Naya Pakistan Housing” programme.

\section{Evolution and Path Creation in Three Pro-Poor Housing Projects}

In the following, we will investigate three vignettes as examples of pro-poor urban housing governance projects: A government-initiated subsidised housing scheme, a privately developed incremental pro-poor settlement, and informal residential areas under regularisation. We conducted qualitative research in all sites discontinuously between 2012 and 2016 as part of two larger research projects on: (1) social mobilisation processes in peri-urban low-income areas of Pakistan; and (2) access to housing and services in the neighbouring cities of Amritsar and Lahore, across the India-Pakistan 
border. Recurrent field research periods in Lahore lasted on average three to four months and covered the time before and after the elections in Punjab province, enabling us to locate the development processes in the three sites in the broader political context. General elections in Pakistan were held on 11 May 2013. As a result, Pakistan Muslim League-Nawaz (PML-N) became the first party in the federal government with Nawaz Sharif as Prime Minister. In Punjab, the PML-N provincial government was re-elected with Muhammad Shahbaz Sharif as Chief Minister of Punjab.

In all three sites, we employed ethnographic fieldwork methods, including informal and in-depth interviews of residents and staff members of the different agencies and companies involved in governance to explore the effect of steering, namely whether and how access to low-income housing is gained, controlled, and maintained. We conducted follow-up interviews with key respondents over the years, which allowed a better understanding of the evolution of governance in the studied housing projects. These methods were complemented by walk-alongs-a combination of selective participant observation with informal interviews with residents in the respective field sites. Our analysis is, therefore, based on observations and interviews gathered as ethnographic fieldnotes, as well as additional documentary materials (e.g., evolving housing policies and regulations, local and national newspaper clips, beneficiaries' allotment letters and payments slips, official newsletters, brochures or reports on the housing projects, among others).

\subsection{Case I-Ashiana: A Public Pro-Poor Housing Scheme}

Ashiana-e-Quaid Lahore is the name of a pro-poor housing scheme initiated in March 2011 by the Punjab provincial government in Lahore. The project was assigned to the Punjab Land Development Company (PLDC) and aimed to provide roughly 2,750 affordable housing units for low-income and vulnerable beneficiaries. PLDC had been set up in 2010 with a specific pro-poor housing mandate by the provincial government (PLDC, 2011; Saeed, 2013) even though entities with similar mandates already existed. Under the direct supervision of the Chief Minister of Punjab, Ashiana received not only land transferred to PDLC but also direct seed funding from the Punjab Government (Ur Rahmaan, 2017). With the land subsidised, low-income residents were to cover the cost of the house only. A bilateral financial agreement between PLDC and the Bank of Punjab (BOP) facilitated access to loans for successful allottees (PLDC, 2012). After the first keys were handed over to residents in late December 2011, the inauguration of the second phase in Ashiana-e-Quaid followed in February 2012, and a new low-income scheme with 10,000 flatsAshiana-e-Iqbal-was launched by PLDC (2012) in cooperation with the LDA preceding elections in 2013. By this time, the Chief Minister of Punjab also acted as LDA chair- man (Provincial Assembly of the Punjab, 2013). After his party (PML-N) won the elections, the speed of work almost froze while Ashiana transformed into a publicprivate enterprise as PLDC and LDA partnered with construction companies (e.g., NESPAK, Bahria Town) and investors for the scheme's development (LDA, 2015). By March 2016, about one-third of the initially planned low-income houses were still to start construction, while many more remained either unfinished or under the control of the constructors despite previous allotment.

To be selected, eligible candidates-those with an individual income below Rs. 20,000 (Kahloon, 2011, p. 4; PLDC, 2011, p. 43), Rs. 30,000 per household (interview with PLDC officer, December 6, 2014), or with proof of belonging to a specific quota-were included in a lottery draw for provisional allotment letters in August 2011. However, for some potential beneficiaries, the necessary 25 percent down payment for the house was too high despite BOP loan provisions. Furthermore, residents indicated that monthly instalments increased by one-third as they had to pay interests to the BOP in the process (interviews, December 8,2014 ). Months after first allottees had moved in, construction remained incomplete, and developers lagged behind with the provision of basic facilities such as water from overhead reservoirs. Instead, water trucks were organised to fill individual houses' water tanks (interviews, May 6, 2012) until water was provided on a regular basis. In consequence, many residents denied paying service charges to what they suspected were fake PLDC employees because they had heard an announcement by the Chief Minister that no service fees would be required until the entire scheme was fully developed (interviews with residents, November 29 and December 6, 2014). However, the slow pace of completion in Ashiana-e-Quaid hindered many allottees from accessing their houses, even though they had paid the down payments. Others who had not, but lost interest in the rights-based access to allotted houses, stopped paying instalments, which reportedly affected the funding sources of the PLDC. PLDC subsequently attracted affluent buyers ready to take over the liabilities of low-income defaulters at negotiated prices close to market value. In another contradiction to the set-out principles for Ashiana's development, PLDC sold and rented informally (interviews with residents, December 6 and 8, 2014). Residents who had moved to Ashiana in 2015 noted that their connections with politicians or influential people enabled them, for example, to trade an allotment letter of a house with a specific number in a specific block that was yet to be completed against another allotment letter in an already finished sector (interviews, September 23, 2015).

The scheme's failure to provide pro-poor housing solutions originates in deeply engrained dependencies of the governance actor/institution configuration, related power dynamics, and underlying planning visions. The strategic mobilisation of the pro-poor housing discourse before the 2013 elections as a top-down, 
fast-track, low-cost housing vision caused fast-paced steering, including early implementation in 2011-12. The LDA/PLDC tandem demonstrated a dominant pathdependent position of provincial development actors in the urban governance framework to the detriment of (lower-tier) local governance institutions. Despite subsidies, the adverse purchasing arrangements for low-income families led to the exclusion of eligible applicants. The disconnect between the market-driven corporatisation, manifest in the interdependence between LDA/PLDC, and construction companies owned by politically influential persons (Dawn, 2016; Siddiqa, 2007) on the one hand, and the slow pace of construction and transfer of completed houses to beneficiaries on the other, points to informal mechanisms of purposive deregulation guided by profit-interests of the actors involved. The leadership of PLDC, together with BOP and Bahria, as well as other contractors, strategically calculated the loss of government property and the benefits of turning Ashiana into a middle-class neighbourhood up for purchase on the open housing market. This allowed exploiting the gap between the real estate value on-site (subsidised due to free land allocation) and the market value that middle-income clients pay in comparable locations where the land plot costs more than the construction of the house. However, allottees practised purposive deregulation, too, when they increasingly perceived allotment arrangements as insecure and denied payment of fees and further instalments. The discretionary decisions and transfers to allottees without a house, in spite of submitted down payments, led to access failure rather than enforcing allottees' rights. Subsequently, they chose access paths through relational mechanisms to realise their rights by investing in relations with politicians and PLDC representatives to secure or maintain access to housing and services.

\subsection{CASE II-KKB-Lahore: Sites and Services Approach}

Khuda Ki Basti Lahore (KKB-L) is the name of a replicated Incremental Housing Scheme (IHS) initiated first by the Pakistani NGO Saiban in Hyderabad Sindh (KKB-1) from 1986 onwards. The founder and chairman of Saiban refers to it as an experiment (Siddiqui, 2014) for providing affordable housing to the urban poor, developing infrastructures on a progressive self-financing model (based on instalments and development charges paid by residents), and for enabling low-income groups, generally excluded from the formal housing market, to access small loans. This IHS approach was initially inspired by the Latin American-origin sites and services schemes (Turner, 1977) that came to be promoted globally by the World Bank from the 1970s onwards.

KKB-L was launched in 2005/06 in the northern periphery of Lahore beyond the River Ravi. One major reason for this remote location was that unlike for KKB-1, where the Hyderabad Development Authority provided the land at subsidised rates, Saiban had to pur- chase the land for KKB-L from private owners at market value. Accordingly, KKB-L was planned on a very small scale, limited to eight hectares for 460 plots. A plot for low-income residents was to cost Rs. 90,000. The authorities approved the plan in exchange for a certain number of mortgaged plots, and since the land was purchased with the help of a Rs. 10 million loan, premium location plots for Rs. 125,000 apiece were integrated in the planning. Potential residents who did not own property already, had a maximum income of Rs. 15,000 and agreed to construct a house and inhabit it for a minimum of five years were accepted as allottees. Given that the plot price was already beyond the means of many, the expenses for constructing the house was the main factor deterring potential settlers, besides issues like the distance to urban Lahore and lack of transport from the settlement to the main road. To counter this, Saiban accepted 25 percent of the cost of the land as a down payment and the rest in monthly instalments. Of those residents who acquired a Rs. 200,000 loan from the Housing Building Finance Corporation for the construction of the house, many, however, opted to construct minimal structures or poor-quality houses and saved the loan for other purposes. By 2014, only about 200 of 460 planned plots were occupied, of which 50 percent remained in default of payment. Moreover, the small socio-spatial scale of KKB-L inhibited the development of economic activities in the settlement, thus leaving constructed shops without leases in the planned commercial sites (interviews, December 13, 17 and 27, 2014).

Residents' ability to benefit from infrastructure and service provision remained limited: Water supply was not yet centralised and proper roads were still not built after ten years of development. A portion of the park was transformed into premium plots, and the community centre laid out in the KKB-L plan was never constructed. Other services such as schooling, a mosque and medical care (dispensary) were available selectively. On the one hand, access to such services depended on outreach and relations ('self-management') of individual block representatives to NGOs and social welfare organisations, the mandates of both were limited. On the other, service provision became linked to identity traits, community cohesion in housing blocks, and location and time of settlement. For example, the NGO-run dispensary and gynaecologist assistance were based on the work of volunteers and could only offer scattered service to residents; the financing of the mosque by donors from a specific Muslim sect excluded the larger part of the settlement population, and road construction was advanced most where residents had settled down and paid service charges longest. This indicates struggles between different interest groups among residents and Saiban for the control over resources and their management and points to underlying webs of power relations. Especially community managers and elected representatives of block committees aspired to become brokers in the development process by attempting to 
monopolise access to developmental charges and NGOs' funds to ultimately control the distribution of benefits for their own constituencies. Rifts between block resident populations emerged, for example, because Pashtuns - who originated from western Pakistan and do not usually have relatives and family support in Lahore and its surroundings-had a clear incentive to establish themselves a home in KKB-L in aspiration of social upward mobility. The decision of many Punjabi families to move to KKB-L mostly from Lahore proper, on the contrary, seems to have been motivated primarily by investment purposes (interviews, December 17 and 21, 2014; November 29, 2015).

While the initial conditions under which KKB-L came into being triggered strong path dependencies, the interplay of dependencies created unanticipated effects for Saiban and hampered the development of the housing scheme. Goal dependencies manifested in the disconnect between the incremental housing discourse that guided the planning of KKB and the fact that some residents did not, or could not, share the idea of communal self-financing and stopped paying instalments. Even where settlers benefitted from Saiban-facilitated loans and payment concessions, these access mechanisms failed to ensure the quality of constructions because of strategic calculations of residents related to the prospect of land speculation (access seizure). It is noteworthy that, despite sanctions, some residents succeeded in acquiring up to eight plots utilising relatives' names that in fact had no intention to move to the settlement; here, initial constructions merely happened to prevent the cancellation of the plots (interviews, December 21, 2014). The low occupation rate and the increase of defaulters affected the cost recovery of instalments and the development of self-financed services causing residents to mobilise relational access opportunities within their immediate community or identity groups or through tapping NGOs and social welfare organisations for facilities and service provision. As a result, each residential block has undergone a different development path based on specific sets of power relations that manifested in different usages of relational access mechanisms and evolved from goal dependencies linked to the different motivations for settling in KKB-L. Taken together, this case exemplifies a failed steering attempt that largely overestimated the ability and willingness of low-income residents to construct and consolidate housing and services on their own. As a result, different urban qualities evolved within the settlement.

\subsection{CASE III-Inchoate Regularisation of Katchi Abadis on Federal Land (Pakistan Railways)}

Mughalpura is the name of an area in Lahore that historically consists of land from the British-Indian North Western State Railway and, after 1947, of the Pakistan Government Railway Transport Company (Pakistan Railways). Refugees arriving from India in 1947 established several irregular colonies (katchi abadi/s) on the vacant land starting from encroachments and makeshift constructions, e.g., Al-Noor Colony, Miraj Colony, Jamilabad, and Dars Bare Mian. Pakistan Railways have tried to evict irregular settlers from its land since the 1950s. Only under Zia-ul-Haq's military government (1978-88), an initial form of regularisation came into effect, entitling katchi abadi dwellers who could prove residence from 1 January 1978 to ownership rights and a subsequent legalisation of status (Government of Punjab, 1987). After a Punjab government survey identified 34 katchi abadis on Railways' land in 1986, these sites were registered for transferral from the Ministry of Railways to provincial jurisdiction for planned regularisation. Without waiting for the necessary non-objection certificates (NOCs), LDA reportedly started to implement development measures and charged service fees and property tax while the transfer of rights was delayed. Even after the provincial government issued the Punjab Katchi Abadis Act 1992 (Government of Punjab, 1992) that newly enacted a 1985 cut-off date, and provided that only the Directorate General (DG) Katchi Abadis Punjab (created in 1987) would have the power to carry out evictions, the Railway Ministry continued to schedule demolitions. During the military government of Pervez Musharraf (1999-2007), the government of Punjab issued a protection order in 2001 to halt demolitions and evictions unless clearance was obtained from the District Coordination \& Monitoring Committee on Katchi Abadis (Government of Punjab, 2001). Furthermore, dwellers were to be compensated in case of necessary relocation. Despite the recognition of katchi abadis as legitimate in the NHP of 2001 and the issuance of the Punjab Katchi Abadis (Amendment) Ordinance 2007 (Government of Punjab, 2007)-enacted later as the Punjab Katchi Abadis (Amendment) Act 2009-that determined the cut-off date 31 December 2006, the reluctance of Railways officials to issue NOCs for LDA and thus to effectively cede land to katchi abadi dwellers remained high. Eviction notices were issued continuously in 2011 and 2012. By early 2012, 36 katchi abadis throughout Lahore were still waiting for NOCs from the Railways. This number included 24 of the 34 that existed before 1985 (interviews, February 28, 2012).

The dwellers of the different katchi abadis in Mughalpura secured access illegally when they first settled on vacant government land. With eviction notices against them and government interventions in their favour, residents navigated steering attempts and increasingly became confident to rely on their own actions in the local governance set-up. For example, when Pakistan Railways targeted Al-Noor and few other colonies in 2000 , they mobilised widespread protests based on the collective action infrastructure of the newly founded All Pakistan Katchi Abadi Alliance (APKAA) and the Lahore-wide Muttahida Action Committee that had existed as a wing of the Social Welfare Society Dars Bare Mian Mughalpura since its registration in 1983 and 
whose president was born in Dars Bare Mian Katchi Abadi as a son of refugees from India. In 2001, APKAA petitioned the government to complete the regularisation of katchi abadis, including the transfer of rights and the implementation of development works, and to put a stop to the Railways' demolition attempts. However, while the share of transferred land in Dars Bare Mian Katchi Abadi amounted to 193,000 square metres of a total of 280,500 square metres by 2014 (Salahuddin, 2014), only 250 out of the 3,500 houses were registered and had attained the legal title. The reason was twofold: Hardly any family could pay the amount of money DG Katchi Abadi staff reportedly requested illegally for titling (Rs. 30,000), and subsequently, residents settled for transfer notification as good-enough tenure security. At the same time, residents' access to services (water, electricity, gas) and infrastructure expanded continuously. With an estimated population of more than 200,000 residents, Mughalpura has regularly had candidates for the National and Provincial Assembly elections line up to pave streets and lanes, finance sewerage systems and erect schools to secure votes (interviews: April 13 and 21, 2012).

This case of pro-poor housing governance did not originate in comprehensive plans but exemplifies responsive steering due to large-scale illegal encroachment on government land. Poor settlers were able to maintain their ability to live on that land through three types of relational access mechanisms: Paying rents to Railways employees, lobbying the government through resistance activities to enact regularisation policies, and serving as vote banks for candidates in political elections in exchange for infrastructure and service development that conversely aided dwellers' access claims. Even though the protests of Railways' katchi abadi dwellers succeeded-especially with the military governments under Zia-ul-Haq and Musharraf-thus forging a kind of goal dependency with the joint aim at regularisation, the policies were not enforced, and residents never gained access control. Incentives for adverse power relations prevailed; especially the increase of real estate prices during the property boom of the 2000s incentivised Pakistan Railways employees to urge evictions and lease out land illegally to interested tenants for personal benefit rather than to have it transferred to LDA for regularisation. Even where land was transferred and title deeds were issued, Railways officials still exercised control through racketeering, i.e., by enforcing fees for any action (extensions, titling, repairs) related to individual houses. This does not only subject katchi abadi dwellers' full tenure security to uncertainty and undermines state policy but also fails to provide sustainable pro-poor housing.

\section{Discussion}

In each of the three case studies, a unique combination of path dependencies, interdependencies, and goal dependencies constituted governance paths and their linear and non-linear specific manifestations. We detected that the different phases and components of steering corresponded with the prevalence of certain forms of dependencies. In a planning stage, actor/institution configurations presented themselves as highly path-dependent, and the development of local visions for pro-poor housing schemes in close relation with international discourses constituted an indicator of goal dependency. It dominated the translation of vision into strategy in a second phase. While thus path and goal dependencies structured the framework for pro-poor housing policy implementation, this crucial phase was characterised by the interplay of power relations-actors negotiating the enforcement of their interests-that manifested in numerous interdependencies. These were mainly responsible for steering outcomes and the extent to which non-linear governance paths evolved. However, all three types of dependencies amplified each other and determined the outcome of steering attempts.

Modes of access to low-income housing in all three cases were determined by strong path dependencies linked to the initial conditions in which the respective project was set. We found path dependencies in Ashiana in the institutional LDA/PLDC tandem overriding local government structures, a mechanism manifest in the evolution of Lahore's urban governance frameworks, where government institutions are entangled at multiple levels and paths of governance simultaneously. The role of the PLDC in Ashiana's actor/institution configuration, the trend towards corporatisation in goal-dependent alignment with the latest development discourse, and subsequently evolved market-driven motivations for the development of the scheme plus profit interests of individuals tangible in speculative strategies, all perpetuated the path dependency. In effect, the steering of pro-poor public housing sector activities derailed. Similarly, in the KKB-L case, goal dependencies manifest in the disconnect between the IHS's 'travelling idea' and the beneficiaries of the communal self-funding model's lack of endorsement limited the target groups' ability to gain and maintain houses and services. The case showed, too, that actors, once established in a specific actor/institution configuration within a highly dependent governance path, found it difficult to alter the direction of governance. When they attempted to do so through informal beneficiary-targeted deregulation via concessions, they produced further dependencies, for example a larger number of defaulters. In the case of katchi abadi colonies, employees of Pakistan Railways (a powerful federal institution with an asset range of land and properties inherited from colonial times) constrained residents' ability to secure access control of housing despite government efforts of 'responsive steering' to regularise low-income informal settlements. The very idea underlying those regularisations can be considered goal dependent, as different governments, civilian and military alike, have aligned, uncritically, to 
the international discourse of granting property rights (de Soto, 2001) to the urban poor-with the assumption that rights-based mechanism alone would ensure access.

The analysis of access mechanisms at work in the three case studies enables us to point out interdependencies that manifest in power relations underlying the respective actor/institution configurations. In all three schemes, rights-based mechanisms (legal and illegal) secured access mostly in connection to other mechanisms. Property rights alone-when available-would not necessarily translate into full access to services. Structural and, particularly, relational access mechanisms proved more influential in enabling or constraining low-income residents' ability to gain, control or maintain access. In Ashiana, connections to politicians and/or the urban development agency could expedite housing delivery and transfers of allotments. In KKB-L, residents could ease the financial effort of purchasing a plot and building a house through formal and informal funding arrangements with the managing NGO. Facilities and service provision could be lobbied via identitybased collective action or by reaching out to NGOs and welfare organisations. In katchi abadi colonies, residents maintained their ability to benefit from housing and services through informal payments, strategies of resistance such as intermittent social mobilisation, and by mobilising their bargaining power as voter bank with politicians. Adverse power relations or structural aspects, however, also constrained benefits from the housing projects and the regularisation programmes. In Ashiana, unfavourable purchasing arrangements operated as powers of exclusion, and the protracted construction process-engrained in the entanglements between urban development actors and their conflicting interests and calculations-hampered the delivery of houses. In KKB-L, the lack of cohesion undermined the equal distribution of benefits. In katchi abadis, the threat of evictions and the strategic pressure tactics by Railways employees through bribes, intimidation, and coercion sustained residents' uncertainty.

The amplifying effect of entangled dependencies in Ashiana was obvious in linkages between the elections and the pace of construction-a combination of goal-, interdependence, and path dependence. Similarly, KKB-L illustrated how the development process was contingent on the payment of fees and the number of beneficiaries willing to reside in KKB-L-and this in return was dependent on the way the NGO managed (or not) to translate the idea of incremental housing into practice. Likewise, in katchi abadis, modes of access were steered by the idea of granting property rights in combination with interdependencies between katchi abadi dwellers through building alliances for social mobilisation and between residents, Railways officers, and development authoritiesi.e., DG Katchi Abadis and LDA. Here it also becomes evident how an institution such as LDA can be part of different actor/institution configurations and influence different governance paths simultaneously. It also points to the existence of multiple governance paths, the entanglements of which are of differentiated quality and extent and non-linear in nature.

Although failures in all three steering attempts responded in one way or another to the interplay of dependencies producing rigidity in the envisioned plans and their implementation, our analysis revealed an alternative path creation that proved flexible and productive. Unanticipated effects were particularly dominant in KKB-L's case since the governance path strongly depended on translating and implementing a largely decontextualised vision - the IHS - into reality. Beneficiarytargeted deregulation from above and purposive deregulation (by defaulting in payments) from below opened a space of negotiating evolutionary governance where access mechanisms continued to be adapted and experimented, thus leaving scope for innovation and improvement. In Ashiana, informal arrangements from above in the allocation of houses also developed and were consequently countered with purposive deregulation by residents refusing to pay fees, selling, and renting houses before legally entitled. However, in this case, the effects of alternative path creation benefited mostly specificwell connected-individuals or well-off bidders and, therefore, progressively abandoned the goal to provide pro-poor housing. In the case of katchi abadi colonies, the failure of responsive steering-since access control was never obtained-has shaped spaces of civil dissent, resistance, negotiation, and cooperation that require constant re-mobilisation to secure good-enough tenure.

\section{Conclusion}

Actor/institution configurations in Lahore pertaining to urban governance and specifically low-income housing have changed over time with transforming political economies. Along with this, possibilities, mechanisms, and strategies to access low-income housing and services have also evolved through rights-based and structural-relational access mechanisms. While the politics of promise by different political regimes in Pakistan created an environment of optimism and political mobilisation for the urban poor, they also led to political and bureaucratic appropriation through various state-led or -supported policies and steering attempts. The process of negotiating these different interests not only 'from below' and 'from above' but also in their mutual interdependencies and continuing path dependencies exemplifies what we call the politics of evolving urban governance.

In this article, we combined access theory with an evolutionary governance approach to analyse how steering attempts get derailed and produce non-linear governance paths. We have demonstrated how the attention to power relations between different urban governance institutions and actors reveals the politics of access to low-income housing and services with three case vignettes from Lahore. Gaining and maintaining 
access was shown to be highly contested among the stakeholders involved. The failures of low-income housing provision-as well as the mitigation strategies to counter these-can therefore be conceived as access struggles, highly political open-ended processes. Once opened, alternative governance paths turned out to be productive for aspiring low-income property owners who, for example, employed civil dissent, social mobilisation, and strategies of resistance ('collective action strategies from below') in the broader sense, and, in this framework, most meaningfully by pursuing informal mechanisms of purposive deregulation. These were guided by profit interests of actor/institution configurations that discouraged low-income occupancy and by allottees and residents' motivations to gain access even if it meant to default on formal rules. In our cases, when the low-income residents employed relational access mechanisms instead of rights-based ones, this contributed to non-linear path creation with ends even more lose, seemingly unpredictable, and in effect pushing evolving urban governance beyond (stated) initial steering intentions. This finding frames the emerged disconnect between urban normative frameworks manifest in urban planning visions and pro-poor housing policies on the one hand and residents' needs and everyday practices on the other. Our insights explain the dismal prospects for resolving the housing crisis in Lahore and in the wider context of Pakistan.

Abstracting from the specific case of Lahore and lowincome urban housing governance in Pakistan, we see the added value of the theoretical merger of access theory and EGT in investigating steering failures in urban governance contexts of other societies-in the so-called Global South, Global East, and Global North. We argue that an EGT-access approach allows tracing the mechanisms underlying the processes through which low-income populations manage to benefit from housing and services across culturally or politically specific contexts. The attention of planners should also be directed towards mutually amplifying dependencies at work. As our cases showed, diverse types of governance dependencies and their interplay constrain the evolution of the planned visions over time, which ultimately risks leading to the reproduction of existing actor/institution configurations, unequal mechanisms of access to housing and services and bundles of powers. Strong path dependencies need to be balanced with calculated non-linearity in path creation to avoid statism and allow productive flexibility to confront challenges and regain shared visions of urban futures. In cities of the Global North, access cum EGT analyses can help to shed light on gentrification mechanisms that often entail the dismantling of public housing and/or the uprooting of low-income residents from renewed and revalued neighbourhoods. In urban agglomerations of the Global South and Global East, these types of analyses can probe further into why different pro-poor housing projects do not deliver stated objectives, i.e., access to housing and ser- vices for low-income and vulnerable populations. Last but not least, the conceptual approach outlined in this article also provides a lens to capture the productive dynamics of evolving non-linear urban governance paths by taking into account forms of agency and collective action strategies of low-income and vulnerable people.

\section{Acknowledgments}

This research was conducted in the framework of the project "Sub-urban movements: Social inequality and dynamics of micro-mobilization" as part of the Research Network 'Crossroads Asia-Conflict, Migration, Development' (Grant No. 01UC1103A), funded by the German Federal Ministry of Science and Research and a Doctoral Research Grant from La Caixa Foundation (Spain) in collaboration with the German Academic Exchange Service (DAAD). We would like to thank all the interviewees for the time they dedicated to this study, the two anonymous reviewers, and the thematic issue editors for their helpful responses.

\section{Conflict of Interests}

The authors declare no conflict of interests.

\section{References}

Ahsan, M. (2019). Making unaffordable to affordable: Looking into affordable housing issues and its remedies. Architecture and Urban Planning, 15(1), 22-29.

Alvi, I. (1997). The informal sector in the urban economy: Low income housing in Lahore. Oxford University Press.

Anjum, G. A., \& Hameed, R. (2007). The dynamics of colonization of peripheral housing schemes and policy options in case of Lahore. Pakistan Journal of Engineering and Applied Sciences, 1, 24-30.

Beunen, R., Duineveld, M., \& Van Assche, K. (2017). Evolutionary governance theory and the adaptive capacity of the Dutch planning system. In G. de Roo \& L. Boelens (Eds.), Spatial planning in a complex unpredictable world of change: Towards a proactive coevolutionary type of planning within the Eurodelta (pp. 98-116). InPlanning.

Beunen, R., Van Assche, K., \& Duineveld, M. (Eds.). (2015). Evolutionary governance theory: Theory and applications. Springer.

Cermeño, H. (2021). Living and planning on the edge: Unravelling conflict and claim-making in peri-urban Lahore. Urban Planning, 6(2), 189-201.

Dawn. (2016, March 30). Malik Riaz on bribes: Blackmail and launching media empire. https://www.dawn. com/news/1248654/malik-riaz-on-bribes-blackmailand-la\%20unching-mediaempire/print

de Soto, H. (2001). The mystery of capital: Why capitalism triumphs in the West and fails everywhere else. Black Swan. 
Fariha, T., Zunaira, Z., Muhammad, S., Javeria, H., Minahil, N., Areesha, G., Sana, M., \& Batool, S. N. (2018). Developing countries perspective on housing affordability: Recommendations for Pakistan. Technical Journal, University of Engineering and Technology (UET) Taxila, Pakistan, 23(2), 1-10.

Gera, N. (2007). Impact of structural adjustment programmes on overall social welfare in Pakistan. South Asia Economic Journal, 8(1), 39-64.

Government of Pakistan. (2018). Pakistan Tehreek-eInsaf (PTI) National Affordable Housing policy. Naya Pakistan Housing Program. http://nphp.com.pk/ government-policy-on-housing

Government of Punjab. (1987). Instructions regarding regulation/development of Katchi Abadies in Punjab. Directorate General Katchi Abadis, Local Government \& Rural Development Department.

Government of Punjab. (1992). Punjab Katchi Abadis Act 1992. Directorate General Katchi Abadis, Local Government \& Rural Development Department.

Government of Punjab. (2001). Order of the Chief Secretary Directorate General Katchi Abadis \& Urban Improvement (Order No. DG(KA\&UI.)/10-3/2001-P.A. in partial modification of the order of same number dated March 29, 2001).

Government of Punjab. (2007). The Punjab Katchi Abadis (Amendment) Ordinance (Ordinance No. XVIII of 2007). The Punjab Gazette.

Javed, N., \& Riaz, S. (2020). Issues in urban planning and policy: The case study of Lahore, Pakistan. In B. Dahiya \& A. Das (Eds.), New urban agenda in Asia-Pacific: Governance for sustainable and inclusive cities (pp. 117-162). Springer.

Jenkins, P., Smith, H., \& Wang, Y. P. (2007). Planning and housing in the rapidly urbanising world. Routledge.

Kahloon, R. M. (2011). Aashiana Housing Project (AHP). Quarterly Research \& News, 2011(14/15), 2-8.

Lahore Development Authority. (2015). Public notice for bidding: Affordable housing units at Ashiana-eQuaid. Lahore.

Malik, A. (2011). Pro poor urban development and the antecedents of poverty and exclusion in Lahore. Pakistan Journal of Urban Affairs, 1(1), 3-13.

Pakistan Bureau of Statistics. (2017). Block wise provisional summary results of 6th Population \& Housing Census-2017 (as on January 03, 2018). https://www.pbos.gov.pk/content/block-wiseprovisional-summary-results-6th-populationhousing-census-2017-january-03-2018
Peluso, N. L., \& Ribot, J. C. (2020). Postscript: A theory of access revisited. Society \& Natural Resources, 33(2), 300-306.

Provincial Assembly of the Punjab. (2013). The Lahore Development Authority (Amendment) Act [LDAAA2013] (Notification No. PAP-Legis-2(15)/2013/979). The Punjab Gazette.

Punjab Land Development Company. (2011). Initial examination report and environment management plan of Ashiana Housing Scheme, Mauza Attari Sabora. Lahore.

Punjab Land Development Company. (2012). Newsletter 2011-2012: Ashiana-e-Quaid housing scheme, Atari Saroba. Lahore.

Qadeer, M. (1983). Urban development in the third world: Internal dynamics of Lahore, Pakistan. Vanguard.

Rana, S. (2013, April 15). What happened to those projects? Unfinished business of 7 successive governments. The Express Tribune. https://tribune.com. pk/story/535696/what-happened-to-thoseprojects-unfinished-business-of-seven-successivegovernments

Ribot, J. C., \& Peluso, N. L. (2003). A theory of access. Rural Sociology, 68(2), 153-181.

Saeed, H. (2013). An evaluation of Ashiana Housing Project, Lahore [Master thesis, University of Engineering and Technology Lahore (UET)].

Salahuddin, S. (2014, April 20). At a land not theirs. The News on Sunday. https://www.thenews.com.pk/tns/ detail/556132-katchi-abadi-in-lahore

Siddiqa, A. (2007). Military Inc.: Inside Pakistan's military economy. Oxford University Press.

Siddiqui, T. (2014). Pakistan's urbanization challenges: Housing for the low-income. In M. Kugelman (Ed.), Pakistan's runaway urbanization: What can be done? (pp. 66-77). The Wilson Center.

Turner, J. F. C. (1977). Housing by people: Towards autonomy in building environments. Pantheon Books.

Ur Rahmaan, A. (2017). Evolution of town planning in Pakistan: With a specific reference to Punjab province. Allied Book Company.

Van Assche, K., Beunen, R., \& Duineveld, M. (2014). Evolutionary governance theory: An introduction. Springer.

Van Assche, K., \& Verschraegen, G. (2008). The limits of planning: Niklas Luhmann's systems theory and the analysis of planning and planning ambitions. Planning Theory, 7(3), 263-283.

\section{About the Authors}

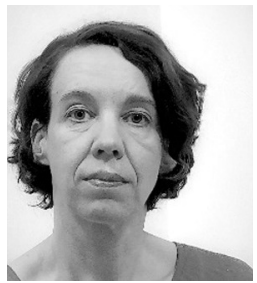

Katja Mielke is Senior Researcher at the Peace and Conflict Research Institute BICC in Bonn, Germany. She holds a PhD degree in Development Research from the University of Bonn. Her main interests are related to questions about entanglements of state-society intersections and local governance in conflict-affected settings with a focus on power relations, legitimation and representation mechanisms, social and political mobilisation, and practices of knowledge production. 


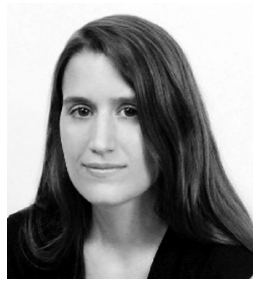

Helena Cermeño is an Architect and Urban Planner, Lecturer, and Research Fellow at the Department of Urban Sociology at the University of Kassel and Junior Researcher at the Centre for Development Research (ZEF) at the University of Bonn, Germany. Her research on India and Pakistan focuses on urban governance and conflicts related to the politics of housing and service provision. 